\title{
Religious Diversity in Modern Orthodox Thought
}

\author{
Paul Ladouceur ${ }^{1,2}$ \\ 1 Orthodox School of Theology at Trinity College, Faculty of Divinity, University of Toronto, Toronto, \\ ON M5S 1H8, Canada; 123thabor@gmail.com \\ 2 Faculté de théologie et de sciences religieuses, Université Laval, Québec, QC G1V 0A6, Canada \\ Academic Editor: John Jillions \\ Received: 4 January 2017; Accepted: 2 April 2017; Published: 27 April 2017
}

\begin{abstract}
This essay explores different approaches to non-Christian religions in Orthodox thought, from the early Fathers to the present day. Among modern Orthodox theologians, Georges Khodr and Anastasios Yannoulatos inherit an inclusivist or tolerant attitude to religious diversity from Justin Martyr and other early Fathers, while Seraphim Rose represents an exclusivist or intolerant position, characteristic of Tertullian. Philip Sherrard's thinking on non-Christian religions can be described as religious pluralism, while that of Lev Gillet is close to comparative theology. Despite the absence of formal Orthodox declarations concerning religious diversity, Orthodox thought on the subject since World War II converges around the notions of inclusivism and comparative theology, considering that non-Christian religions are mysteriously "included" in the missions of Christ and the Holy Spirit in the world and that their adherents can achieve salvation as understood in Christianity.
\end{abstract}

Keywords: religious diversity; Christianity; non-Christian religions; Orthodoxy; Justin Martyr; Georges Khodr; Anastasios Yannoulatos; exclusivism; inclusivism; religious pluralism

\section{The Early Fathers and Non-Christian Religions}

Early Christian thinking on non-Christian religions was conditioned by the pagan polytheism of the Roman Empire, religious aspects of Greek philosophy and links between Christianity and Judaism; including the incorporation, not without some hesitation, of the Jewish sacred books into the Christian Bible. Some early Christian thinkers, especially St Justin Martyr (c.100-c.165) had a cautiously positive view concerning the existence of elements of truth among pagan philosophers and Jewish sages, while Tertullian (c.155-c.240) represented a less tolerant view, which became more dominant in later Christian thinking. Later in history, Orthodoxy had extensive historical experience, not entirely negative, of life as a religious and cultural minority under non-Christian regimes in Persia, the Arabic Middle East and the Ottoman Empire. For long centuries Christian communities were in a 'survival mode' under Muslim rule in these areas, which made theological reflection on the meaning of religious diversity in God's plan for salvation difficult. Only in recent times have Orthodox theologians begun to reflect more systematically on the theological significance of non-Christian religions, especially as Orthodoxy is increasingly confronted with this reality both in countries of Orthodox immigration in Western Europe and North America, and increasingly in countries of Orthodox tradition. Contemporary Orthodox attitudes towards religious diversity are often linked with thinking on secularism, human rights and the religious policy of the State.

Several notions concerning non-Christian religions which have come down to us from the ancient Fathers are still relevant. The most important is no doubt from Justin Martyr, who applies the Hellenistic notion of the "seeds of the Logos" (logos spermatikos) in a Christian sense. Although there is some question of what exactly Justin meant by the term, his writings suggest that he was referring to those aspects of Christian truth present in the philosophers. Michel Fédou defines Justin's doctrine of the logos spermatikos as "a universal divine communication in the world of the nations, in the 
expectation of the full revelation of the Logos of God at the moment of the Incarnation (Fédou 2009)." Justin recognizes that pagan philosophers, especially Socrates and Plato, had a degree of knowledge of truth, but that the fullness of truth resides only in Christian revelation. He even goes so far as to refer to certain Greek philosophers and various Jewish figures as Christians:

We have been taught that Christ is the First-born of God, and we have suggested...that he is the logos of whom every race of men and women were partakers. And they who lived with the logos are Christians, even though they have been thought atheists; as, among the Greeks, Socrates and Heraclitus, and people like them; and among the barbarians ${ }^{1}$, Abraham, and Ananias, and Asarias, and Misael, and Elias (Justin Martyr 1997, First Apology, 1.46).

For whatever either lawgivers or philosophers uttered well, they elaborated according to their share of logos by invention and contemplation. But since they did not know all that concerns logos, who is Christ, they often contradicted themselves (Justin Martyr 1997, Second Apology, 1.10).

In his polemical treatise Against the Heathen, St Athanasius of Alexandria (c.296-373) recognizes, like Justin before him, the possibility that pagans can rise to knowledge of truth. Possessing a rational soul and free will, pagans can abandon idolatry and return to the true God:

Just as they turned away from God with their mind and invented gods from nonexistent entities, so they can rise towards God with the mind of their soul and again turn back towards him. They can turn back if they cast off the stain of all desire which they have put on, and wash themselves until they have eliminated every addition foreign to the soul and show it unadulterated, as it was made, in order that in this way they may be able to contemplate therewith the Word of the Father, in whose image they were made in the beginning (Athanasius 1971, 1.34).

Other early Christian thinkers who recognized the existence of goodness and elements of truth in pagan religions, and especially in the philosophers, include Clement of Alexandria (c.150-c.215), Origen (c.184-c.253), Basil the Great (329-379), Gregory Nazianzus (329-390) and Augustine (354-4302).

But a critical evaluation of other religions also found support in early Christianity, inheriting the negative attitude towards pagan idolatry in both the Old Testament and the New Testament. Tertullian represents the more conservative strain of early Christian thought, seeing in other religions only the work of demons, and more specifically considering that pagan gods are demons. In his Apology, Tertullian sets out to demonstrate to his pagan addressee that the pagan gods and demons are the same beings under different appellations, "that the nature (qualitas) of both terms is the same (Tertullian 1950, 1.23.4)."

Tertullian suggests that if a Christian were to interrogate a person possessed by an evil spirit and a person considered to be under the influence of a god (for instance, a priestess of Cybele), both would confess that they are inhabited by a devil (Tertullian 1950, 11. 23.4-6). To him this clearly proves the falsity of the demons' pretension to divine status, since even if the spirits' admission is a lie it shows that "your [i.e., pagan] divinity has become subject to the Christians" and, therefore, is not a true divinity (Tertullian 1950, 1.23.8). If pagan ideas about the divine were true the demons would never usurp it, nor would the gods deny it when questioned by a Christian (Tertullian 1950, 1.23.10). Tertullian concludes that, since he has proven that the beings whom pagans worship are not gods, his interlocutor must confess them to be devils (Tertullian 1950, 1.23.).

\footnotetext{
Justin is writing between 155 and 157 to the Emperor Antoninus (ruled 138 to 161). The "barbarians" here are the Jews. For an overview of early Christian thinking on other religions and philosophies, see (Giannoulatos 1971, pp. 13-31; Sherrard 1998, pp. 55-61).
} 
Tertullian acknowledges that some philosophers openly attack pagan superstitions and have the same teachings on morality and virtue as Christians. Yet he criticizes the philosophers, such as Socrates, for corrupting truth by offering sacrifices to false gods and by ranking demons next to gods. These corruptions of the truth, according to Tertullian, ensure that the philosophers are tolerated in the Roman Empire, while Christians-who uphold the truth in all respects-suffer persecution (Tertullian 1950, 1.46).

Byzantine thinking on non-Christian religions was strongly influenced by shifting attitudes toward Judaism and, later, towards Islam. From the more tolerant and open early approaches of Justin, Clement and others, subsequent writings on non-Christian religions moved to more a more hostile and intolerant approach. Islam was first seen as a Christian heresy because of its rejection of the divinity of Christ, notably by St. John of Damascus (676-749) ${ }^{3}$. But subsequent Byzantine attitudes varied from anti-Jewish and anti-Islamic polemics to attempts at theological dialogue, such as in the writing of St. Gregory Palamas (1296-1359) during his captivity by the Turks in 1354-1355 before he was finally released for a ransom ${ }^{4}$.

The two positions can be summarized thus: that non-Christian religions contain elements of truth and can somehow be assimilated to Christianity; and that they are false doctrines, works of demons intended to lead Christians astray, or more broadly, have no merit for salvation. These two strands of ancient Christian thinking about non-Christian religions, and especially Greek philosophy, have come down to modern times.

\section{Modern Orthodox Thought on Religious Diversity}

The relationship between Orthodoxy and non-Christian religions has not featured highly on the modern Orthodox theological agenda. Major twentieth-century theologians such as Sergius Bulgakov, Vladimir Lossky, Georges Florovsky and John Zizioulas have not addressed the question directly. Some leading figures of the Russian religious renaissance of the late nineteenth and early twentieth centuries, notably Vladimir Soloviev, Pavel Florensky and Sergius Bulgakov, reflected on the thorny issue of Jewish-Christian relations, but these writings do not lead to a coherent theology of religious diversity. On the other hand, certain features of the Christologies and ecclesiologies of these theologians are relevant to a theology of religious diversity. Bulgakov writes, for example, in his major work on the Church The Bride of the Lamb (1945):

The doctrine of the Church as the body of Christ, as the temple of the Holy Spirit, has, first of all, an anthropological significance. This doctrine affirms a certain pan-christism and pan-pneumatism, to which no limits are set. In this aspect this doctrine contains the idea that, after the Incarnation and the Pentecost, Christ is the head of humankind and therefore lives in all humankind. The same thing is affirmed concerning the Holy Spirit.

The limits of the Church mystically or ontologically coincide with the limits of the power of the Incarnation and the Pentecost; but these limits do not exist at all. "And the Word was made flesh" (Jn 1:14); the incarnation of the Lord as the divine-human person of Christ consisted in the assumption of the whole Adam, "perfect" humanity. There are no limits to this assumption, either external or internal. Christ's humanity is the inner human condition of every human being ... All human beings belong to Christ's humanity. And if this human condition is the Church as the body of Christ, then, in this sense, all humanity belongs to the Church (Bulgakov [1945] 2002, pp. 261, 266).

3 Islam features as "Heresy 101" under the title "Against the Ishmaelites" in Against Heresies, a contested work attributed to John of Damascus. Another work by the Damascene is "Disputation between a Christian and a Saracen." For the Greek text of the former and selections from the latter, with English translations, see (Janosik 2016). See also earlier references in (Giannoulatos 1971, n.54, p. 34)

4 On this episode and the resulting writings of Palamas, see (Arnakis 1951) and (Sloboda 2017). 
Bulgakov's Christological, Pneumatological and ecclesiological universalism as reflected here can be interpreted to suggest that Christ and the Holy Spirit act beyond the visible limits of Christianity and that non-Christian religions are somehow "included" in the mystery of the Church. This is of course speculative since Bulgakov did not explicitly extend his thinking to non-Christian religions ${ }^{5}$.

Orthodox ecclesiology since the mid-nineteenth century has devoted considerable attention to Orthodoxy in relation to other Christian churches and confessions, but very little on non-Christian religions. Nonetheless, several theologians have written significantly on the question. We shall focus here on the main lines of thought of Orthodox figures who represent a broad range of approaches to religious diversity. Their writings on non-Christian religions are not extensive, consisting mainly of articles, essays and chapters in books, but nonetheless sketch out basic elements of Orthodox thinking, both positive and negative, on non-Christian religions.

One of the earliest modern presentations of an Orthodox position on non-Christian religions was an address by Metropolitan Georges Khodr of Mount Lebanon (b. 1923) at the Central Committee of the World Council of Churches in Addis Ababa in 1971, under the title "Christianity in a Pluralistic World-The Economy of the Holy Spirit (Khodre 1971a; Khodre 1971b; Kinnamon and Cope 1997)." Khodr, a leading Orthodox ecumenist and promoter of dialogue between Christianity and Islam, argues for a vision of the Church as "the instrument of the mystery of the salvation of the nations" by appeals to the Noahic covenant, divine freedom and kenosis, the universality of the economy of Christ and especially the Resurrection, and the mysterious, unbounded presence of the Holy Spirit. "The Church's task is to perceive...even in the world of the religions," writes Khodr, "the God who is hidden within it, in anticipation of the final concrete manifestation of the Mystery (Khodre 1971a, p. 197)." Khodr's bold thinking culminates in a universal and eschatological vision of world religions:

Christ is hidden everywhere in the mystery of his self-abasement. Any reading of religions is a reading in Christ. It is Christ alone who is received as light when grace visits a Brahmin, a Buddhist or a Moslem reading his scriptures. [...] All who are visited by the Spirit are the people of God. The Church represents the first-fruits of all humanity called to salvation. [...] The main task is to identify all the Christic values in other religions, to show Christ as their bond and his love as their fulfillment (Khodre 1971a, pp. 198, 200, 202).

But Khodr does perhaps get carried away with himself in one statement: "Every martyr for truth, every man persecuted for what he believes to be justice, dies in union with Christ (Khodre 1971a, p. 198)." This sweeping hypothesis requires a deeper exploration, since extremists of all sorts may be persecuted and die for what they believe to be right.

Together with Georges Khodr, Archbishop Anastasios Yannoulatos (b. 1929) is another leading figure in Orthodox thought concerning religious diversity. Yannoulatos studied theology and world religions in Athens and in Germany and served as Acting Archbishop in East Africa from 1981 to 1991, becoming primate of the Orthodox Church of Albania in 1992. In 1971 he published a survey of the evolution of Christian thinking on non-Christian religions from the early Church to the Second Vatican Council, including patristic, Byzantine, Protestant and Roman Catholic approaches over the centuries (Giannoulatos 1971). In a 1974 essay, Anastasios Yannoulatos grounds an Orthodox approach to non-Christian religions in the theology of the human person and the need for humans to exist in communion with other persons, a "communion [koinonia] of love," which takes as its point of departure and model the communion among the divine Persons of the Holy Trinity. Yannoulatos has no hesitation in showing his colors: "The universality of the Church does not mean exclusivity; it means all-inclusiveness (Yannoulatos 2003, p. 29)." And later in the same essay he writes: "People who have different beliefs never lose the basic attributes of their spiritual identity: they never cease to be 'children of God,' created in 'in God's image,' and hence our brothers and sisters. God is the Father of

5 This line of speculation can be read into other Orthodox thinkers whose ecclesiology is also universalist, for example Vladimir Soloviev (Soloviev 1948), especially pp. 99-102. 
us all (Yannoulatos 2003, p. 43)." While this approach reiterates the ontological equality of all humans regardless of religion or even non-religion, it does not, as Yannoulatos recognizes, deal with the more specific issue of a theological understanding of non-Christian religions: "An analysis of Christian theories on how to understand other religions will not be undertaken here. I believe that a satisfactory solution to this problem has not yet been found. We are still looking (Yannoulatos 2003, p. 43)."

In a 1989 paper Yannoulatos tackles head-on the issue of the theological significance of non-Christian religions. After a brief historical survey of Christian attitudes towards other religions from the earliest times, Yannoulatos classifies Christian theories and attitudes towards other religions into six categories, covering the full gamut from Tertullian's view that non-Christian religions are the work of the devil, to relativism and syncretism (Yannoulatos 1989, pp. 132-35). Building on his earlier Trinitarian foundation of human relations, he postulates three key concepts for an Orthodox theology of religions. First, the "universal radiance of God's glory": there is but one God, even if people have widely-diverging conceptions about God; hence, "God's glory pervades all of heaven and earth and every shape and form of life (Yannoulatos 1989, pp. 139-40)." The second principle is founded on the ontological equality of all humans, who thus have a common origin and destiny, extended to include universal divine revelation: "The universal character of divine revelation to humanity is related to our innate religious sense." (Yannoulatos 1989, p. 141). Yannoulatos' third principle is universal divine providence. God constantly provides for creation and humanity: "God has never stopped caring for the whole world that he created." (Yannoulatos 1989, p. 141). Yannoulatos refers to God's covenants with Adam and Eve (Gn 2:16-17) and with Noah (Gn 9:8-17). Like Khodr before him, Yannoulatos considers that the Noahic covenant is universal, permanent and all-pervasive, not only between God and Noah, but to all Noah's descendents, "all flesh that is on the earth" (Gn 9:16). "All human beings," he concludes, "are in a relationship with God through some previous covenant to which he himself set his own seal." (Yannoulatos 1989, pp. 141-42).

These fundamental principles serve as the underpinning of a Christological basis of an Orthodox understanding of other religions, not in an exclusivist sense of barring those who do not know or acknowledge Christ from salvation, but to affirm, with Justin Martyr and other early Christian writers, that Christ, the Logos of God, is "the true Light which gives light to every man coming into the world" (Jn 1:8). But Yannoulatos also ventures into more perilous territory by affirming that it is the constant activity of the Holy Spirit which assures "the manifestation of the Trinitarian God's presence-everywhere in the world, throughout time and for all eternity," and "continues to act for the salvation of every person and the fulfillment and completion of the entire world (Yannoulatos 1989, p. 149)." Yannoulatos appears to subscribe here to the theory of a twofold divine economy, attributed to Vladimir Lossky, whereby Christ is active primarily among Christians and the Holy Spirit among non-Christians. In his book The Mystical Theology of the Eastern Church (1944), Lossky devotes a chapter to "The Economy of the Son" and another to "The Economy of the Holy Spirit." This suggests a real distinction in the economies of the Second and Third Persons of the Holy Trinity, assumed to be respectively within Christianity and beyond the boundaries of Christianity. Although Lossky does not actually assert distinct "economies" of the Son and the Holy Spirit in the world, he is criticized for implying this ${ }^{6}$.

While Yannoulatos does not really clarify the respective roles of Christ and Holy Spirit in world religions, he does affirm that "the criterion by which Christians evaluate and accept different religious ideas and principles is Jesus Christ, the Word of God and incarnation of God's love." (Yannoulatos 1989, p. 152).

Philip Sherrard (1922-1995) was an English scholar, author and translator who contributed greatly to increasing awareness of Modern Greek culture and literature, especially poetry. Sherrard also wrote

6 For criticisms of Lossky's The Mystical Theology of the Eastern Church, see (Zizioulas 1994; Florovsky 1958; Verkhovsky 1958; Vassiliadis 1991). 
on a wide range of philosophical and theological themes. In his book Christianity: Lineaments of a Sacred Tradition (1998), he presents one of the most open views of religious diversity of any Orthodox writer. From a call for the Church to renounce "the claim that the Christian revelation constitutes the sole and universal revelation of the universal Truth" (Sherrard 1998, p. 53), Sherrard goes on to enunciate an inclusivist position following on Georges Khodr: "Any deep reading of another religion is a reading of the Logos, of Christ. It is the Logos who is received in the spiritual illumination of a Brahmin, a Buddhist, or a Moslem." (Sherrard 1998, p. 62). But he goes much further, expounding a doctrine of religious pluralism (in the technical sense): "Sacred traditions other than their own [Christians'] are divinely-instituted ways of spiritual realization... There may be as many ways to God as there are individual human beings [...] Since God is infinite, there is nothing to prevent him from choosing to reveal himself in an infinite number of limited forms, all of which he himself, in his non-manifest nature, infinitely transcends." (Sherrard 1998, pp. 63, 70).

The foundation of Sherrard's position is a conviction of a unity of truth, "an underlying metaphysical order, a series of timeless and universal principles from which all derives and on which all depends... the essential unity of the unchanging, non-manifest, and timeless principles themselves." (Sherrard 1998, pp. 62, 63). Sherrard is expressing here the central teaching of the "traditionalist" or "perennialist" school of thought. This school, following its principal modern architects the philosophers René Guénon (1886-1951) and Aldous Huxley (1894-1963), emphasizes the existence of primordial and universal truths upon which all major world religions draw as their prime source. "There is the Truth," writes Sherrard, "as it is 'laid up in heaven' in its preformal and purely metaphysical state; and there is this Truth as it is when translated into the various doctrines and symbolic languages of the human race." (Sherrard 1998, p. 64). Sherrard leaves open the possibility that one religious tradition may more fully express the metaphysical Truth than others. "Certain forms" in which God reveals himself may "enshrine his reality more fully than others"; one religious tradition rooted in true revelation may "express God's wisdom and knowledge more fully than others." (Sherrard 1998, pp. 70, 73-74). But Sherrard stops short of claiming that Christianity, let alone Orthodoxy, is precisely the tradition that most fully and accurately reflects divine reality or the transcendent Truth of which he speaks.

Nicholas Arseniev (1888-1977) taught Orthodox theology in Russia until 1920, then in Königsburg and Warsaw until 1939 and after World War II at St Vladimir's Seminary in New York. In his book Revelation of Life Eternal (1960), Arseniev sketches an outline of a Christian attitude towards the religious quests and beliefs of humanity beyond Judeo-Christian revelation, based on the premise "that there is a certain knowledge of God or a yearning and craving and searching after him given to all." (Arseniev 1982, p. 41). Arseniev explores this theme from the perspective of the simultaneous existence in religious traditions of both "a higher conception or rather a higher experience of God" and "the rubbish and trash of often morally repulsive and even ludicrous polytheistic and polydemonistic conceptions." (Arseniev 1982, p. 47). But even in animistic religions dominated by the latter, there may occur a "breaking through" of a higher conception of divinity, such as the notion of a "merciful Supreme Father." Arseniev gives a number of examples, from the Bushmen of South Africa, the Hinayâna Buddhist notion of nirvana, the Aztecs of Mexico and the Pygmies of Africa. He challenges a long-held view that there has been an evolution in the history of religion from lower to higher forms. Citing examples from anthropological studies of religious beliefs and practices in pre-modern societies, Arseniev argues that "in many cases [there] seems to be an evolution of descent, of religious deterioration." (Arseniev 1982, pp. 47-51, 53-58). Arseniev's perspective on non-Christian religions is decidedly committed: the values represented in the Judeo-Christian tradition are the standard against which he measures other religious traditions and practices.

Fr. Lev Gillet (1893-1980) was engaged in interreligious dialogue long before any formal interreligious movement. Gillet, better known under his pen-name "A Monk of the Eastern Church," 
was a French Catholic priest and monk who joined the Orthodox Church in Paris in 1928 ${ }^{7}$. In 1938 he moved to England, where he was closely associated with the Fellowship of Saint Alban and Saint Sergius. Engaged in Jewish-Christian relations, in his first years in England he was chaplain for a hostel occupied by young Jews and Jewish Christian refugees from Germany and Austria until the British authorities interned its occupants as "enemy aliens" in early 1940. The Religious Society of Friends (Quakers) then provided Gillet a fellowship to study Jewish theology and Jewish-Christian relations, the result of which was a remarkable and pioneering book, Communion in the Messiah, published in 1942 at the height of World War II (Gillet [1942] [2003] 2013). Going beyond advocating Christian solidarity with persecuted Jews in Hitler's Europe, Gillet sets out to identify points of convergence between Jewish and Christian theology, spirituality and religious practices. He focuses, as the title of book indicates, on the notion of the Messiah, and also other common theological insights such as the Jewish shekinah, the divine Presence or indwelling ${ }^{8}$.

After the war, Gillet worked for many years for the Union for the Study of Great Religions based in London, preparing "book lists" for the Union's journal—in effect, reviews of publications relevant to interreligious understanding. Gillet was also Secretary of the World Congress of Faiths devoted to interreligious dialogue for five years (1961-1965). One of his responsibilities was to prepare meetings of the Congress, including acting as resource person for interfaith services-no small challenge. Gillet never wrote explicitly about his interreligious experience, but it is likely out of these activities that he published a unique series of meditations focused on the notion of Supreme Being as "limitless love $e^{9}$. (Gillet 1971).

A sharp contrast with the Orthodox personalities that we have considered so far, Fr. Seraphim Rose (1934-1982), an American convert to Orthodoxy, inherits the Tertullian strand of early Christian thought concerning non-Christian religions. Rose's main concern in his book Orthodoxy and the Religion of the Future (1975) is to expose and denounce forms of religious and quasi-religious beliefs and spirituality which became widespread in the United States after World War II, including Islam, Hinduism, yoga, zen, transcendental meditation, Hare Krishna, Maharaj-ji, the charismatic revival, the New Age, personal sects typified by the Jonestown Massacre of 1978, and Unidentified Flying Objects (UFOs) - the components, one surmises, of "the religion of the future." Rose's objective is to warn Orthodox believers about the dangers of straying from the Orthodox faith inherent in these movements, but the book suffers from categorical language and weak theological justification for affirmations and critiques. Rose goes on to condemn Orthodox participation in the ecumenical movement and in inter-religious dialogue, casting the entire book in an anti-ecumenical, denunciatory, conspiratorial and apocalyptic vision of exotic religious movements threatening Orthodoxy.

Rose writes that dialogue with non-Christian religions is the product "of a diabolical 'suggestion' that can capture only those who have already departed so far from Christianity as to be virtual pagans: worshippers of the god of this world, Satan (2 Cor 4:4), and followers of whatever intellectual fashion this powerful god is capable of inspiring." (Rose 1975, p. xxix). His main Orthodox target here is none other than Georges Khodr, severely taken to task for his January 1971 address to the Central Committee of the World Council of Churches. Rose accuses Khodr of leading "the avant-garde of Orthodox apostates" who "speak of the 'spiritual riches' and 'authentic spiritual life' of the non-Christian religions." (Rose 1975, pp. xxix-xxx). Rose raises several serious theological objections to Khodr, including Khodr's "projections" of Christ into non-Christian religions, the problem of Khodr's statement about martyrs for truth dying in communion with Christ, and Khodr's apparent separation of the economy of the Holy Spirit from the economy of Christ (Rose 1975, pp. xxx-xxxi). Rose misrepresents the last point as: "It is the 'Holy Spirit,' conceived as totally independent of Christ and his Church, that is really the

7 See Élisabeth Behr-Sigel's masterly biography (Behr-Sigel 1993), English version (Behr-Sigel 1999). The subtitle of the French is missing in the English.

8 On the Shekinah, see (Gillet [1942] [2003] 2013, pp. 80-87, 138, 228-29).

9 See the discussion in (Behr-Sigel 1993, pp. 515-19, 556-68). 
common denominator of all the world's religions." (Rose 1975, p. xxxi). For Rose, this is then a heresy because it "denies the very nature of the Holy Trinity" with "no aim but to undermine and destroy the whole idea and reality of the Church of Christ." (Rose 1975, p. xxxi). Stripping away the impetuous language, Rose raises but does not resolve the major theological issue concerning the respective roles of Christ and the Holy Spirit beyond the visible boundaries of the Church, especially in non-Christian religions, and indeed in people of good faith without religious belief.

\section{Orthodoxy and Theologies of Religious Diversity}

The thinking of ancient Fathers and of modern Orthodox theologians on non-Christian religions can be considered in the light of typologies of interreligious theology. In 1983, the Anglican theologian Alan Race (b. 1951) put forward a three-fold typology of Christian attitudes to non-Christian religions based on the possibility of salvation outside Christianity (Race 1993). An exclusivist position is grounded on the imperative and universal finality of divine revelation in Christ. It considers that non-Christian religions are globally "excluded" from the history of salvation, as summarized by Marianne Moyaert expressing the exclusivist position: "The divine incarnation in Christ is... ontologically constitutive for salvation. But not all are redeemed: only those who recognize Jesus Christ as their personal Savior sent by God can be redeemed." (Moyaert 2012, p. 27). Christians are those who are called to salvation in Christ; non-Christian religions cannot offer salvation, leaving non-Christians beyond salvation. As we saw above, among the ancient Fathers Tertullian is considered the pre-eminent exponent of exclusivism. The inclusivist position considers that non-Christian religions carry certain truths and values of Christianity, despite their errors, and can thus be considered as somehow "included" in the mystery of Christ and the mission of the Holy Spirit among the nations: "Salvation is still Christological, but in an ontological rather than epistemological sense: one can be saved even without knowing Christ at all." (Moyaert 2012, p. 30). Justin Martyr, Clement and Origen reflect this inclusivism. Religious pluralism goes further than inclusivism by considering that all great religious traditions are of divine origin and are equally valid paths to God and to salvation. Religious traditions, Christianity included, "constitute different ways of experiencing, conceiving and living in relation to a transcendent divine Reality which transcends all our varied visions of it." (Hick [1989] 2004, pp. 235-36).

Both exclusivism and inclusivism are essentially faith-based theologies which agree on the universality of Christ and Christian revelation. Religious pluralism, while not incompatible with Christianity, takes a more restrictive view of the significance of Christ and Christianity by considering Christianity as one religion among many, all legitimate paths to God. In contrast, the ancient Fathers did not consider Christianity to be simply one path to God among others, but inherently superior because of its divine origin and divine Founder and Head. Eminent modern representatives of these three theologies of religious diversity are often considered to be the Protestant theologian Karl Barth (1886-1968) (exclusivism); the Catholic theologian Karl Rahner (1904-1984) (inclusivism); and the Anglo-American philosopher of religion and theologian John Hick (1922-2012) (religious pluralism) ${ }^{10}$.

In addition to this typology of Christian attitudes towards non-Christian religions, a slightly different polarity is based on the extent of Christian claims in the face of other religions. Absolutism considers that only Christianity is absolute or universal, in that Christianity alone has the fullness of truth and thus the universal claims of other religions are false. Both exclusivism and inclusivism are forms of absolutism or universalism. At the opposite pole, relativism accords the same value to all religions. Christianity is seen as one religion among others, with no stronger claim to truth than other religions, or to no religion for that matter. A form of relativism lies at the theoretical base of religious pluralism and of the modern, secular, religiously-neutral state- even if the state itself incorporates certain Christian notions.

10 Foundational writings include notably (Brunner and Barth 1946; Rahner 1966, pp. 115-34; Hick 1973). 
Pushed to an extreme, exclusivism and absolutism can lead to religious fundamentalism, typically characterized by intolerance, even to hostility and violence against other religions and their followers. At the other end of the spectrum, religious pluralism, carried to its limits, can open the door to syncretism: attempts to associate in one religious vision beliefs and practices from different traditions which may or may not be inherently irreconcilable, such as attempts to incorporate reincarnation into Christianity (Ladouceur 2006, p. 214).

Although Race's three-fold typology became commonplace in interreligious studies, it has been under increasing criticism since the late 1990s and has undergone a process of refinement, with sub-categories of each basic approach identified ${ }^{11}$. The main critique is that it is based on Christian soteriology - who can be saved in terms of Christ's salvific mission-and thus does not allow non-Christian religions to be themselves as human responses to the fundamental questions of the existence of the world and the meaning of life.

Other models have come forward in response to critiques of soteriological typology. Against a Christian soteriological view of world religions is particularism, which emphasizes distinctiveness and differences among world religions. Particularism, founded on a cultural-linguistic outlook, argues that "religions are thought of primarily as different idioms for construing reality, expressing experience and ordering life," according to leading advocate George Lindbeck (b. 1923), an American Lutheran theologian (Lindbeck 1984, p. 47). This approach proposes no common framework for comparing religions, but rather, in contrast with universal claims of religions and notions of perennial philosophy, emphasizes irreducible differences among religions "that cannot be traced back to a common ground or universal structure." (Moyaert 2012, p. 35). Different religions "may have incommensurable notions of truth, of experience and of categorical adequacy, and therefore also of what it would mean for something to be most important (i.e., 'God')." (Lindbeck 1984, p. 49). Apart from widely varying ideas concerning the nature of a Supreme Being, such irreconcilable differences could include notions such as karma and reincarnation, versus redemption and a single life, and nirvana versus heaven, the Kingdom of God or even the Orthodox conception of theosis.

The comparative theology approach also seeks to understand religions in themselves, but goes beyond this to identify points of congruence and divergence among religions. Like particularism, comparative theology discards a priori interpretative schemes (such as Christian soteriology) and "a global meta-perspective on religion," but instead "sets out to understanding the meaning of the Christian tradition by exploring it in the light of the teachings of other religious traditions." (Moyaert 2012). Comparative theology allows religions to speak for themselves-there is considerable emphasis on the study of primary sacred texts—but at the same time examines them from a Christian standpoint, not as a neutral bystander. It aims at bringing views of different religious traditions "into dialogue and even argument," writes the American Jesuit Francis Clooney (b. 1950), a leading advocate of comparative theology, "and thus promote a new, more integral conversation wherein traditions can remain distinct although their theologies are no longer separable. A religion may be unique, but its theology is not." (Clooney 2001, p. 8).

In comparison with the diversity and maturity of modern Orthodox thinking on the Church, and indeed on ecumenical theology, Orthodox theological reflection on religious diversity is still in its formative stages. Metropolitan Georges Khodr and Archbishop Anastasios Yannoulatos are pioneers in the field, despite the small number of their writings devoted to the subject. In the soteriological model of religious diversity, Khodr and Yannoulatos represent inclusivist theological positions concerning non-Christian religions, with a cautiously positive outlook on religious diversity, while upholding the universality of Orthodoxy's claims. Nicholas Arseniev also represents an inclusivist approach with perhaps some elements of comparative theology, but without hesitating to critique cruder

11 For overviews of critiques of the soteriological typology, see (Moyaert 2012; D'Costa 2009, pp. 1-54). 
aspects of non-Christian religious practices such as human sacrifice, which he assimilates to lower religious manifestations ${ }^{12}$.

Fr. Seraphim Rose, highly critical of both Orthodox involvement in ecumenism and interreligious dialogue, represents an Orthodox exclusivist position, spilling into fundamentalism (but not to the point of advocating physical violence against non-conformists). Opponents of an inclusivist approach to religious pluralism typically make no attempt to reconcile an entirely negative view of other religions with divine goodness and providence; a theology of the universal import of Christ's salvific mission; or divine goodness with the creation of a large portion of humanity with no opportunity to accede to Christianity and hence, according to exclusivist theology, beyond salvation. The question of religious diversity has not featured on the agenda of Orthodox neo-traditionalists or fundamentalists, other than Seraphim Rose. They have largely focused their energies on attacking ecumenism and Orthodox believers engaged in ecumenical endeavors. Nonetheless the logic of the neo-traditionalist approach to non-Orthodox Christians suggests that the neo-traditionalists would rally to the exclusivist camp-if their theology excludes non-Orthodox Christians from the Church and salvation, to be consistent they would also exclude non-Christians as well.

Philip Sherrard could be identified with religious pluralism as defined above. Although Sherrard vacillates between inclusivism and religious pluralism, many statements in his book Christianity: Lineaments of Sacred Tradition point in the latter direction. Religious pluralism in the strict sense is unlikely to appeal to many Orthodox theologians since it appears to entail a surrender of the universal claims of Christian revelation and the missions of Christ and the Holy Spirit in favor of a relativistic approach to religious diversity. In contrast, the main line of Orthodox thought would see Christ as the perennial philosophy who shines forth, however obscurely at times, in non-Christian religions: "I am the Way and the Truth and the Life" (Jn 14:6).

Fr. Lev Gillet's approach to Judaism in his book Communion in the Messiah and, as far as we are aware, his work for the Union for the Study of Great Religions and the World Congress of Faiths, make him an Orthodox pioneer in comparative theology. Parallel with his commitment to building bridges between Orthodox and other Christians, Gillet sought to highlight what religious traditions share in common rather than focus on fundamental differences. Yet he certainly never lost or diluted his commitment to Orthodoxy. Unfortunately, he never wrote a reflective piece on his approach to religious diversity, and even Élisabeth Behr-Sigel says little about this aspect of his life in her biography of Fr. Lev.

The Holy and Great Council of the Orthodox Church held in Crete in June 2016 did not pronounce itself on religious diversity as such, but several Council documents contain positive statements on religious diversity. The document "The Mission of the Orthodox Church in Today's World" endorses Orthodox involvement in promoting inter-religious harmony: "The various local Orthodox Churches can contribute to inter-religious understanding and co-operation for the peaceful co-existence and harmonious living together in society, without this involving any religious syncretism." (Holy and Great Council 2016c, §A.3). The Council's Encyclical and the Message state that "Honest interfaith dialogue contributes to the development of mutual trust and to the promotion of peace and reconciliation." The only other reference in the Council's decisions to non-Christians is a restatement of the long-standing Orthodox practice of refusing marriages between Orthodox and non-Christians: "Marriage between Orthodox and non-Christians is categorically forbidden in accordance with canonical akribeia." (Holy and Great Council 2016a, §II, 5, iii.; Holy and Great Council 2016b, §17).

Ecumenical Patriarchs Athenagoras I (Kokkinakis) (1886-1972; patriarch 1948-1972) and Bartholomew I (Archontonis) (b. 1940; patriarch since 1991) manifest an open yet discerning attitude towards non-Christian religions. In conversations with the French theologian Olivier Clément,

12 Other Orthodox who endorse an inclusivist approach include (Karmiris 1980); (Constantelos 1992), also in (Swidler and Mojzes 1990); and (Papademetriou n.d.). 
Athenagoras I refers to similarities between Orthodox and Islamic practices of the invocation of the Name of God and the practice of "fools for God" and to the important place that Jesus occupies in Islam. He is confident that "the old suspicions [between Muslims and Christians] are subsiding and will continue to subside" (Clément 1969, p. 176)—this was in 1968, before the rise of Islamic radicalism. In a similar vein, Bartholomew I makes positive remarks about Judaism, Islam, Hinduism and Buddhism - and even the New Age movement-as partial reflections, even if distorted, of the Logos of God (Clément 1997, pp. 197-226). Bartholomew I sees points of convergence between Orthodox and Jewish theology in such areas as primacy of the person, divine energies and divine presence in creation, wisdom, divine kenosis and aspects of spirituality. At the same time he is realistic in recognizing that there are also fundamental divergences and even contradictions on essential questions among major religions, as in his critique of the absence of a notion of a subsisting human person in Hinduism and Buddhism (Clément 1997, pp. 222-24), and in his address to the Conference on Interreligious Dialogue held in Istanbul in March 1998 (Bartholomew I. 1998, Second Period, 5, I, pp. 103-7; Metropolitan Emmanuel of France 2010).

In this admittedly limited survey of modern Orthodox theologians, religious inclusivism emerges as the preferred Orthodox theology of religious diversity, with Georges Khodr and Anastasios Yannoulatos as leading representatives together with Ecumenical Patriarchs Athenagoras I and Bartholomew I. Although the principal representatives of the Russian religious renaissance did not elaborate a formal theology of religions, the universalist ecclesiology of Sergius Bulgakov for one is also consistent with inclusivism. In authors such as Nicholas Arseniev and Lev Gillet, upholding the universal claims of Christianity opens to a comparative theological approach to world religions. This places Orthodox inclusivists in a comparable attitude towards non-Christian religions and philosophies as Justin Martyr, Clement and other early Fathers of the Church, extending Christ's salvific mission to non-Christians (to the extent that it is valid to project the modern soteriological typology unto the ancient Fathers). Seraphim Rose inherits the exclusivist theology of Tertullian, while Philip Sherrard seems to advocate a theology of religious pluralism based on perennialist philosophy. There are no representatives of the particularist approach in our survey-in fact, few Orthodox theologians are scholars of non-Christian religions, with Georges Khodr (Islam) and Lev Gillet (Judaism) as exceptions. With his book Communion in the Messiah (1942), Gillet can be considered a forerunner of comparative theology. Comparative theology lends itself to interreligious contact and dialogue, in which both Khodr and Gillet were engaged.

Despite an Orthodox preference for inclusivist and comparative theology approaches to non-Christian religions, there are still major unresolved questions. These include the extent of Christ's salvific mission beyond the limits of Christianity, divine inspiration in other religious traditions and their sacred writings, non-Christian religions as valid paths to God and salvation, the relationship of Christ and the Holy Spirit in world religions, and the status of non-Christians with respect to the Church. The arrival of large numbers of non-Christian migrants and refugees from the Middle East, Africa and Asia in Western Europe and North America, and, to a more limited extent, in countries of Orthodox tradition, should stimulate greater attention to the development of a robust Orthodox theology of religious diversity.

Conflicts of Interest: The author declares no conflict of interest.

\section{References}

Arnakis, G. Georgiades. 1951. Gregory Palamas among the Turks and Documents of His Captivity as Historical Sources. Speculum 26: 104-18. [CrossRef]

Arseniev, Nicholas. 1982. Revelation of Life Eternal: An Introduction to the Christian Message. Yonkers: St Vladimir's Seminary Press.

Athanasius. 1971. Against the Heathen. In Contra Gentes and De Incarnatione. Oxford: Clarendon Press.

Bartholomew I. 1998. Greeting. (Conference on Interreligious Dialogue [Istanbul, March 7, 1998]). Orthodoxia (January-March): 103-7. 
Behr-Sigel, Élisabeth. 1993. Un Moine de l'Église d'Orient, le père Lev Gillet: Un libre croyant universaliste, évangélique et mystique. Paris: Le Cerf.

Behr-Sigel, Elisabeth. 1999. A Monk of the Eastern Church, Fr. Lev Gillet. London: Fellowship of Saint Alban and Saint Sergius.

Brunner, Emil, and Karl Barth. 1946. Natural Theology. London: Geoffrey Bles/Centenary Press.

Bulgakov, Sergius. [1945] 2002. The Bride of the Lamb. Translated by Boris Jakim. Grand Rapids, Eerdmans and Edinburgh: T\&T Clark.

Clément, Olivier. 1969. Dialogues Avec le Patriarche Athénagoras. Paris: Fayard.

Clément, Olivier. 1997. Conversations with Ecumenical Patriarch Bartholomew I. Crestwood: St Vladimir's Seminary Press.

Clooney, Francis. 2001. Hindu God, Christian God: How Reason Helps Break Down the Boundaries between Religions. New York: Oxford University Press.

Constantelos, Demetrios J. 1992. The Attitude of Orthodox Christians toward Non-Christians. Brookline: Holy Cross Orthodox Press.

D'Costa, Gavin. 2009. Christianity and World Religions: Disputed Questions in the Theology of Religions. Chichester: Wiley-Blackwell, pp. 1-54.

Fédou, Michel. 2009. La doctrine du Logos chez Justin: Enjeux philosophiques et théologiques. Kentron 25: 145-58.

Florovsky, Georges. 1958. Review of the English translation of Vladimir Lossky's The Mystical Theology. The Journal of Religion 38: 207-8. [CrossRef]

Giannoulatos [Yannoulatos], Anastasios. 1971. Various Christian Approaches to Other Religions (A Historical Outline). Athens: Poreuthentes.

Gillet, Lev. [1942] [2003] 2013. Communion in the Messiah: Studies in the Relationship between Judaism and Christianity. London: Lutterworth; Clarke, James, Eugene: Wipf \& Stock.

Gillet, Lev. 1971. Un Moine de l'Église d'Orient. In L'Amour Sans Limites. Chevetogne: Éditions de Chevetogne. Translation in Gillet, Lev. 1977. In Thy Presence. London: Mowbray, Crestwood: St. Vladimir's Seminary Press.

Hick, John. 1973. God and the Universe of Faiths. London: Macmillan.

Hick, John. [1989] 2004. An Interpretation of Religion: Human Responses to the Transcendent. New Haven and London: Yale University Press.

Holy and Great Council. 2016a. The Sacrament of Marriage and Its Impediments. Available online: https: / / www.holycouncil.org/- / marriage (accessed on 23 December 2016).

Holy and Great Council. 2016b. Encyclical of the Holy and Great Council of the Orthodox Church. Available online: https: / /www.holycouncil.org/-/encyclical-holy-council (accessed on 23 December 2016).

Holy and Great Council. 2016c. The Mission of the Orthodox Church in Today's World. Available online: https://www.holycouncil.org/-/mission-orthodox-church-todays-world (accessed on 23 December 2016).

Janosik, Daniel J. 2016. John of Damascus, First Apologist to the Muslims. Eugene: Pickwick Publications.

Justin Martyr. 1997. The First and Second Apologies. New York: Paulist Press.

Karmiris, Ioannis. 1980. The Universality of Salvation in Christ. Theologia 51: 645-91. (Theologia 52: $14-45$ [in Greek]).

Khodre, Georges. 1971a. Le Christianisme dans un monde pluraliste: L'économie du Saint-Esprit. Irénikon 44: 191-202.

Khodr, Georges. 1971b. Christianity in a Pluralistic World: The Economy of the Holy Spirit. The Ecumenical Review 23: 118-28. Reprinted in Sobornost (Summer 1971); Sourozh 53 (August 1993): 9-18.

Michael Kinnamon, and Brian Cope, eds. 1997. The Ecumenical Movement: An Anthology of Key Texts and Voices. Geneva: WCC Publications.

Ladouceur, Paul. 2006. Christianisme et réincarnation. Contacts, Revue Française D'orthodoxie 58: 238-56.

Lindbeck, George. 1984. The Nature of Doctrine: Religion and Theology in a Postliberal Age. London: SPCK.

Metropolitan Emmanuel of France. 2010. Keynote Address. International Council of Christians and Jews. June. Available online: www.ccjr.us/dialogika-resources/documents-and-statements/e-orthodox/1013emmanuel2010june22 (accessed on 28 December 2016).

Moyaert, Marianne. 2012. Recent Developments in the Theology of Interreligious Dialogue: From Soteriological Openness to Hermeneutical Openness. Modern Theology 28: 25-52. [CrossRef]

Papademetriou, George. n.d. An Orthodox Christian View of Non-Christian Religions. Available online: www. goarch.org/ourfaith/ourfaith8089 (accessed on 28 October 2016).

Race, Alan. 1993. Christians and Religious Pluralism: Patterns in the Christian Theology of Religions. London: SCM Press. 
Rahner, Karl. 1966. Christianity and the Non-Christian Religions. In Theological Investigations. London: Darton, Longman Todd, vol. 5, pp. 115-34.

Rose, Seraphim. 1975. Introduction. In Orthodoxy and the Religion of the Future. Platina: St. Herman of Alaska Brotherhood.

Sherrard, Philip. 1998. Christianity: Lineaments of a Sacred Tradition. Brookline: Holy Crosss Orthodox Press.

Sloboda, Nazar. 2017. The Conversations of Gregory Palamas during His Ottoman Captivity. Available online: http://www.academia.edu/12253003/THE_CONVERSATIONS_OF_GREGORY_PALAMAS_DURING_ HIS_OTTOMAN_CAPTIVITY_1354-1355_(accessed on 3 March 2017).

Soloviev, Vladimir. 1948. Russia and the Universal Church (1889). London: Geoffrey Bles/Centenary Press.

Leonard Swidler, and Paul Mojzes, eds. 1990. Attitudes of Religions and Ideologies toward the Outsider. Lewiston: Edward Melon.

Tertullian. 1950. Apology. In Apologetical Works and Minucius Felix Octavius. Washington: Catholic University of America Press.

Vassiliadis, Petros. 1991. Greek Theology in the Making, Trends and Facts in the 80s-Vision for the 90s. St Vladimir's Theological Quarterly 35: 33-52.

Verkhovsky, Serge. 1958. Review of Vladimir Lossky The Mystical Theology of the Orthodox Church. St Vladimir's Theological Quarterly 2: 52-54.

Yannoulatos, Anastasios. 1989. A Theological Approach to Understanding Other Religions. London: Facing the World. Yannoulatos, Anastasios. 2003. Toward a Global Community: Resources and Responsibilities (1974). In Facing the World: Orthodox Christian Essays on Global Concerns. Crestwood: WCC/St. Vladimir's Seminary Press, pp. 15-47.

Zizioulas, John. 1994. The Church as Communion: A Presentation on the World Conference Theme. In On the Way to Fuller Koinonia: Official Report of the Fifth World Conference on Faith and Order. Edited by Thomas F. Best and Günther Gassmann. Geneva: World Council of Churches Publications.

(C) 2017 by the author. Licensee MDPI, Basel, Switzerland. This article is an open access article distributed under the terms and conditions of the Creative Commons Attribution (CC BY) license (http://creativecommons.org/licenses/by/4.0/). 